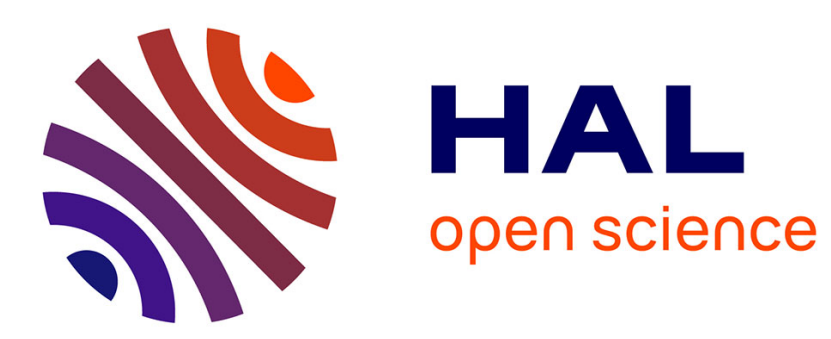

\title{
An advance in the in vitro rearing of stingless bee queens
} Cristiano Menezes, Ayrton Vollet-Neto, Vera Fonseca

\section{To cite this version:}

Cristiano Menezes, Ayrton Vollet-Neto, Vera Fonseca. An advance in the in vitro rearing of stingless bee queens. Apidologie, 2013, 44 (5), pp.491-500. 10.1007/s13592-013-0197-6 . hal-01201317

\section{HAL Id: hal-01201317 https://hal.science/hal-01201317}

Submitted on 17 Sep 2015

HAL is a multi-disciplinary open access archive for the deposit and dissemination of scientific research documents, whether they are published or not. The documents may come from teaching and research institutions in France or abroad, or from public or private research centers.
L'archive ouverte pluridisciplinaire HAL, est destinée au dépôt et à la diffusion de documents scientifiques de niveau recherche, publiés ou non, émanant des établissements d'enseignement et de recherche français ou étrangers, des laboratoires publics ou privés. 


\title{
An advance in the in vitro rearing of stingless bee queens
}

\author{
Cristiano Menezes ${ }^{1,2}$, Ayrton Vollet-Neto ${ }^{2}$, \\ Vera Lucia Imperatriz FonSECA ${ }^{2,3}$ \\ ${ }^{1}$ Embrapa Amazônia Oriental, Belém, PA, Brazil \\ ${ }^{2}$ Faculdade de Filosofia Ciências e Letras de Ribeirão Preto, Universidade de São Paulo, Ribeirão Preto, SP, Brazil \\ ${ }^{3}$ Universidade Federal Rural do Semi Árido, Mossoró, RN, Brazil
}

Received 23 April 2012 - Revised 10 January 2013 - Accepted 23 January 2013

\begin{abstract}
Stingless bees are a diverse group of highly eusocial tropical bees and potential pollinators of natural and crop environments. Nevertheless, large-scale breeding for agricultural purposes still needs development. A bottleneck is the small number of queens generally found in the colonies of most species. A proposed solution is to develop in vitro rearing of stingless bee queens, which includes a technical support due to the massive liquid feeding of larvae. In this study, we tested the efficacy of in vitro queen-rearing techniques in terms of queen size, survival, and fecundity. We found that humidity must be kept high during the first 6 days of larval development and reduced thereafter to $75 \%$. In the most effective treatments, we obtained up to $97.9 \%$ queen survival. We also found that queens not different in size from natural queens could be produced if sufficient larval food is provided. In vitro queens were able to mate and lay viable eggs. This methodology is also useful for several research appliances, like pesticide effect on bees, pollen quality effect in caste determination, and the use of genetic sources for selection programs, among others.
\end{abstract}

\section{Scaptotrigona depilis / Meliponini / colony multiplication / meliponiculture / pollinator}

\section{INTRODUCTION}

Unlike honeybees and bumblebees, the eusocial stingless bees do not provision their brood progressively. All Meliponini species mass provision their brood with liquid larval food, which is a mixture of pollen, gland secretions, and honey (Michener 1974; Hartfelder and Engel 1989). The queen then lays an egg on the top of the food, and the workers close the brood cell. The brood cells are only opened when the adult bees emerge (Michener 1974; Nogueira-Neto 1997).

In most of Meliponini genera (except Melipona), queens are reared in larger brood cells, called royal cells, whereas males and

Corresponding author: C. Menezes, menezes.cristiano@gmail.com Manuscript editor: James Nieh workers are reared in smaller brood cells (Darchen and Delage-Darchen 1971; Engels and Imperatriz-Fonseca 1990). Generally, royal cells are provisioned with up to eight times more larval food than worker and male cells (Darchen and Delage-Darchen 1971; Camargo 1972a, b). In all genera of Meliponini, except for Melipona, female larvae develop into queens if they receive the larger amount of larval food (Camargo 1972a, b; Campos and Costa 1989; Campos and Coelho 1993). In Melipona bees, a large number of queens are produced (up to $25 \%$ among the females), and queens do not receive larger amounts of larval food. Their castes seem to be determined by both genetic and trophic factors, but the mechanism that triggers queen development is still unresolved (Hartfelder et al. 2006). Therefore, in Melipona bees, it is not possible to induce queen production by adding larger amount of larval 
food, as in other stingless bee genera (MacielSilva and Kerr 1991).

Manipulation of larval feeding as an attempt to artificially produce queens has been investigated in Brazil. Camargo (1972a) pioneered these studies and developed a technique for rearing stingless bee larvae in vitro, under controlled conditions, based on existing methods for honeybee queen rearing. Artificial cells were built with honeybee wax and filled with larval food harvested from recently built brood cells. A young larva from a worker cell was then transferred to this artificial cell, where more larval food could be added. The cell was then closed and kept in incubators with controlled environmental conditions. In this way, all female larvae could be induced to become queens.

The initial experiments were performed with Scaptotrigona postica, and other researchers later extended the technique to some other species (Almeida 1974; Campos and Costa 1989; Maciel-Silva \& Kerr 1991; Hartfelder and Engels 1992). Although these studies have been very important in understanding the basic mechanisms of caste determination in stingless bees, the technique was very rudimental, and generally, survival rate was very low. For example, in the first publication of Camargo (1972a), out of 40 trials, only one queen emerged. Although this survival rate increased later to around $50 \%$, several aspects of the technique still needed to be improved. The queens produced under in vitro conditions were smaller than natural queens (Hartfelder and Engels 1992; Baptistella et al. 2012), and building of wax cells was very laborious. Besides that, it is not clear whether these in vitro queens were able to mate and lay eggs.

Additionally, up to now, all efforts to produce queens in vitro were for basic research purposes. Earlier studies also suffered from small sample sizes. Nowadays, with the advance of meliponiculture and its potential application in agricultural pollination (Cortopassi-Laurino et al. 2006), this technique has a greater importance for producing large numbers of stingless bee colonies, similar to what occurred in apiculture. Advances of queen-rearing techni- ques of honeybees (Apis mellifera) improved beekeeping possibilities and were the base of genetic improvement programs, allied with instrumental insemination (Laidlaw and Page 1997; Cobey 2007).

Moreover, the number of royal cells built varies from one species to another. In some stingless bee species, royal cells are rarely seen in the nest, and within the same species, it is influenced by many factors (Imperatriz-Fonseca and Zucchi 1995). Some of these species are good candidates to be used as crop pollinators, and beekeepers could benefit from in vitro queen-rearing technique. For example, Tetragonisca angustula, an important pollinator of strawberry, produces a low number of virgin queens, three to six queens per year (Prato 2011).

The present study tests several modifications of the previous methodology for in vitro queenrearing and the influence of these modifications on survival rate and size of the produced queens. Experiments focused the control of relative humidity throughout larvae development; the success rate of queens produced with the use of acrylic artificial cells; the control of quantities of larval food and queen size; and detection of other possible bottlenecks during in vitro queen-rearing. We also tested whether the in vitro produced queens are able to mate and lay eggs.

\section{MATERIAL AND METHODS}

\subsection{Study site and study species}

The experiments were performed at University of São Paulo, campus of Ribeirão Preto (São Paulo State, Brazil). We used Scaptotrigona depilis (Moure 1942) for this study. This species is a medium-sized bee $(0.5 \mathrm{~cm})$ and live in perennial colonies with around 10,000 bees and a single physogastric queen, which lays around 300 eggs per day.

\subsection{General description of in vitro queen-rearing technique}

We used the technique described by Camargo (1972a) with modifications, as described above. Instead of wax cells, we used commercially available 
ELISA acrylic plates for immunology tests (Figure 1). Each plate has 96 cavities of $7 \mathrm{~mm}$ of diameter and $10 \mathrm{~mm}$ of depth, similar size to natural royal cells of the studied species, S. depilis. All the materials were washed with boiling water and sterilized under UV for 15 min to avoid contamination with external organisms.

The larval food used in the experiments was removed from recently built combs containing around $50-100$ brood cells. The cells were opened; the eggs were removed with a forceps, and the liquid larval food was poured on a container. It was homogenized with an automatic pipette (drawing up the larval food and dispensing it several times) and then distributed amongst the artificial cells. The volume of larval food in each cell varied according to each experiment, as described below.

To avoid excessive damage to source colonies, we harvested only one or two young combs per hive. Each source colony was used once every 15 days without any considerable damage. To produce 100 queens, we needed four to five recently built combs containing around 50-100 closed brood cells to obtain larval food and another comb with young larvae.

The young larvae, between 0 and 1 day old, were obtained from healthy $S$. depilis colonies. The age of the larvae was estimated by their size and position in the brood comb, e.g., recently hatched larvae are close to cells containing eggs. In each rearing plate, we used larvae from three different colonies. Brood

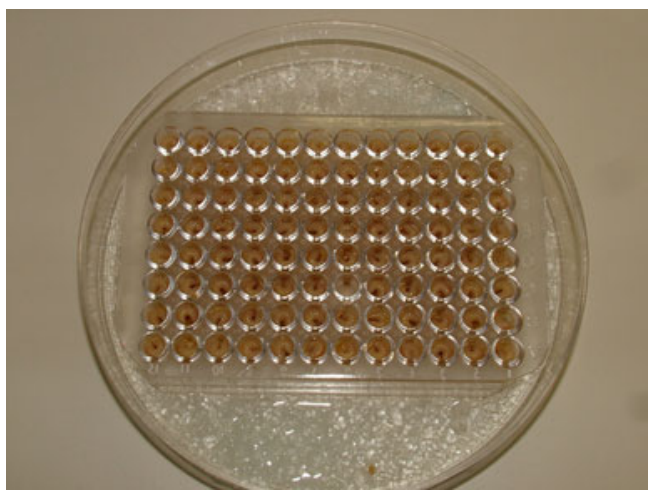

Figure 1. Acrylic plate used for in vitro queen rearing of $S$. depilis. It is placed in a Petri dish filled with saturated salt solution to control humidity levels. cells were opened, and, using a small hook, larvae were transferred to the artificial cells, where they were left floating on the surface of the larval food. The acrylic plates were then placed on Petri dishes $(150 \times 30 \mathrm{~mm})$, placed in an incubator at $28^{\circ} \mathrm{C}$, which is the standard temperature used in previous studies and between the natural range, $26-32{ }^{\circ} \mathrm{C}$ (Engels et al. 1995). They were monitored daily until larvae became pupae, after which they were monitored every 3 days.

\subsection{Ideal humidity conditions to larval development}

So as to ascertain the ideal humidity for larval development, larvae were reared in different humidity conditions throughout their development. The rearing plates were kept inside Petri dishes, and humidity was controlled by filling the bottom of the Petri dish with either a saturated salt solution or pure water (Figure 1). To maintain humidity at $75 \%$, we used $\mathrm{NaCl}$; to maintain humidity at $85 \%$, we used $\mathrm{KCl}$, and to maintain humidity at $100 \%$, we used pure water (Winston and Bates 1960).

The use of saturated solutions is a precise method for controlling humidity in biological research. Winston and Bates (1960) provide a long list of compounds that can be used at various temperatures. We chose $\mathrm{NaCl}$ and $\mathrm{KCl}$ which keep humidity around $75 \%$ and $85 \%$, respectively, at $25-30{ }^{\circ} \mathrm{C}$. We used a hygrometer to verify if our breeding system was working properly.

In each treatment, we prepared 96 cells with food and larvae. In all treatments of this experiment, we put $134 \mu \mathrm{L}$ of larval food in each artificial cell, which was similar to the average amount of larval food we found in natural royal cells $(n=10$ cells, mean $=134.0$, $\mathrm{SD}=15.8$ ). The volume of larval food from royal cells was measured with graduated capillary.

We tested the following humidity treatments: (1) $100 \%$ humidity during all development period; (2) $85 \%$ during all development period; (3) $75 \%$ during all development period; (4) $100 \%$ during the first 3 days and $75 \%$ during the additional days of development; (5) $100 \%$ during the first 6 days and $75 \%$ during the additional days of development; (6) $100 \%$ during the first 3 days and $85 \%$ during the additional days of development; (7) $100 \%$ during the 
first 6 days and $85 \%$ during the additional days of development; (8) $100 \%$ during the first 3 days, $85 \%$ during the next 5 days, and $75 \%$ during the additional days of development; (9) $100 \%$ during the first 6 days, $85 \%$ during next 5 days, and $75 \%$ during the additional days of development.

The criteria used to determine the day at which each humidity level was applied was based on the results of treatments 1,2 , and 3. The most relevant evidences were water accumulation around the larvae and larval food dehydration.

After queens emerged, we measured 30 queens produced in treatments $4,5,8$, and 9 and compared them with 30 queens produced in natural royal cells. We chose these treatments because they resulted in good survival rates (over $75 \%$ ) and larval development was healthy. The other treatments presented many problems due to fungal growth on the pupae and larval food dehydration, which influenced queens' size. The natural queens used in this experiment were collected from 30 different colonies about 2 days before emergence. We used the intertegular distance as the queen size parameter.

\subsection{Influence of quantity of larval food on queens size}

In this experiment, we provided larvae with different volumes of larval food so as to ascertain the quantity of food necessary to produce queens of the same size as natural queens. Three volumes were used 120,134 , and $150 \mu \mathrm{L}$. All of them received the same humidity treatment (treatment 5:100\% during the first 6 days and $75 \%$ during the additional days of development). Thirty queens of each group were measured and compared with 30 naturally produced queens.

\subsection{Are in vitro queens able to mate and lay eggs?}

To test whether in vitro queens are able to mate and lay eggs, 50 queenless nests were produced, and each one received three in vitro queens between 3 and 5 days old. The queens were marked with paint on their thorax and introduced inside a wax pot with holes at their wall, which were slowly opened by workers, to avoid rejection.
Each nest received one brood comb containing about 350 pupae, 150 young workers, building materials, one pollen pot, and one honey pot. The colonies were closed for 1 week to avoid attacks by ants and phorid flies, and to allow workers to build and organize essential structures inside the nest. Before opening the hives, we inspected all the nests to verify if at least one marked queen was accepted by the workers and was still alive.

After 1 week, the hives were opened to the environment and placed on shelves, $30 \mathrm{~cm}$ from each other and facing in the opposite direction to their neighbors. They were inspected once a week for egg laying.

Colonies were fed with one pollen pot and one honey pot every 15 days. If and when a queen started laying eggs, the colony received one more brood comb containing about 350 pupae so as to strengthen the colony further.

\subsection{Statistical analyses}

We used ANOVA to test whether humidity treatments influenced queen size. Tukey's multiple comparison tests were used to compare one treatment to another separately. To test whether the quantity of larval food provided to larvae influenced queen size, we also used ANOVA and Tukey's tests. We used the program Prism 5 (1992-2007, GraphPad Software, Inc.).

\section{RESULTS}

\subsection{Ideal humidity conditions for larval development}

The highest humidity condition (treatment 1) caused water accumulation inside artificial cells. Consequently, all larvae were submerged and died around 7 days after being transferred. Water accumulation also occurred in treatments 5,7 , and 9 , but the exchange of water by salt solution on the sixth day promoted water evaporation from the cell, saving the brood but otherwise not affecting larval development.

On the other hand, low humidity levels caused larval food to dry out. At $75 \%$ humidity (treatment 3), larval food dehydrated completely, and all larvae died by day 11 . At $85 \%$ of 
humidity (treatment 2), only food on the borders of the plastic comb dried out. Although many larvae survived in this treatment, they ingested only a small quantity of larval food and thus became workers.

Treatments in which humidity was at first high and then reduced on the third or sixth day after transfer were more successful, up to $97.9 \%$ of survival (Table I). In general, larvae ingested most of larval food available, but there was always some left on the bottom of the artificial cells at pupation. At the pupa stage, mortality was high when humidity was kept at $85 \%$, and there was intense fungal proliferation, especially on feces and larval food remains. In treatments with $75 \%$ of humidity during the pupa stage, there was very little fungus proliferation and high survival (Figure 2).

The humidity conditions influenced the size of queens produced (ANOVA, $F=28.69 ; R^{2}=$ $0.44 ; P<0.0001$ ) (Figure 3 ). When the humidity inside the Petri dish was reduced on day 3 after transfer (treatments 4 and 8), the produced queens were smaller, probably because the larval food dried out and thus the larvae stopped eating earlier than larvae from treatments where the humidity was reduced later (treatments 5 and 9). However, all of the queens produced in this experiment (treatments 4, 5, 8, and 9) were smaller than natural queens (Tukey's test, $P<0.05$ ) (Figure 3).

Table I. Humidity treatments tested for in vitro queen-rearing of $S$. depilis, survival rates, and general observations.

\begin{tabular}{llll}
\hline $\begin{array}{l}\text { Treatment } \\
\text { number }\end{array}$ & Humidity Conditions & $\begin{array}{l}\text { Survival } \\
\text { rate }\end{array}$ & General observations \\
\hline
\end{tabular}

\begin{tabular}{|c|c|c|c|}
\hline 1 & $100 \%$ during all development period & $0 \%$ & $\begin{array}{l}\text { Water accumulated around larvae at } \\
\text { the sixth day; all larvae died }\end{array}$ \\
\hline 2 & $85 \%$ during all development period & $66.7 \%$ & $\begin{array}{l}\text { Larval food dried at the acrylic plate } \\
\text { borders; only workers emerged }\end{array}$ \\
\hline 3 & $75 \%$ during all development period & $0 \%$ & $\begin{array}{l}\text { Larval food dried out completely; all } \\
\text { larvae died }\end{array}$ \\
\hline 4 & $\begin{array}{l}100 \% \text { during the first } 3 \text { days and } 75 \% \\
\text { during the additional days of development }\end{array}$ & $89.6 \%$ & Healthy development \\
\hline 5 & $\begin{array}{l}100 \% \text { during the first } 6 \text { days and } 75 \% \\
\text { during the additional days of development }\end{array}$ & $97.9 \%$ & $\begin{array}{l}\text { Water accumulated around larvae at the } \\
\text { sixth day but diminished after humidity } \\
\text { reduction; healthy development }\end{array}$ \\
\hline 6 & $\begin{array}{l}100 \% \text { during the first } 3 \text { days and } 85 \% \\
\text { during the additional days of development }\end{array}$ & $53.1 \%$ & $\begin{array}{l}\text { Water accumulated around larvae at the } \\
\text { sixth day; high mortality between the } \\
15 \text { th and 30th day; intense fungus } \\
\text { proliferation at pupa stage }\end{array}$ \\
\hline 7 & $\begin{array}{l}100 \% \text { during the first } 6 \text { days and } 85 \% \\
\text { during the additional days of development }\end{array}$ & $60.4 \%$ & $\begin{array}{l}\text { Water accumulated around larvae at the } \\
\text { sixth day; high mortality between the } \\
\text { 14th and 24th day; intense fungus } \\
\text { proliferation at pupa stage }\end{array}$ \\
\hline 8 & $\begin{array}{l}100 \% \text { during the first } 3 \text { days; } 85 \% \text { during } \\
\text { the next } 5 \text { days; and } 75 \% \text { during the } \\
\text { additional days of development }\end{array}$ & $97.9 \%$ & Healthy development \\
\hline 9 & $\begin{array}{l}100 \% \text { during the first } 6 \text { days; } 85 \% \text { during } \\
\text { next } 5 \text { days; and } 75 \% \text { during the } \\
\text { additional days of development }\end{array}$ & $75.0 \%$ & $\begin{array}{l}\text { Water accumulated around larvae at the } \\
\text { sixth day; high mortality between the } \\
\text { 14th and 23th day; intense fungus } \\
\text { proliferation at pupa stage }\end{array}$ \\
\hline
\end{tabular}

Ninety-six larvae were tested in each treatment 


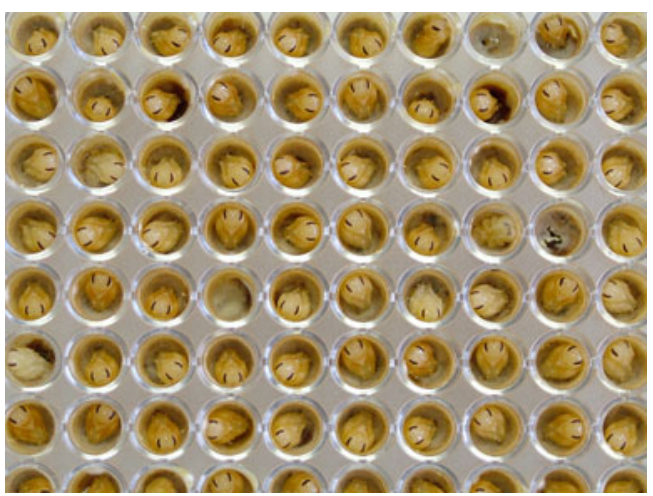

Figure 2. Acrylic cells of in vitro queen-rearing of $S$. depilis with high survival rates at pupa stage.

\subsection{Influence of quantity of larval food on queen size}

The size of queens is also influenced by the quantity of larval food eaten by the larvae
(ANOVA, $F=91.60 ; \quad R^{2}=0.70 ; \quad P<0.0001$ ) (Figure 4). All the experimental groups were significantly different between each other in relation to size (Tukey's test, $P<0.05$ ). However, there was no significant difference between the group fed with $150 \mu \mathrm{L}$ of larval food and natural queens (Tukey's test, $P>0.05$ ) (Figure 4).

\subsection{Challenges during the experiments}

The acrylic cells used for producing in vitro queens did not present any problems during larval development. When the larvae stopped eating, they weaved a silk cocoon around themselves inside the cell. The cell itself remained opened during the entire larval development stage.

We observed some filamentous fungus growing at the borders of artificial brood cells, but they did not represent a problem to larvae survival. We also found this fungus inside

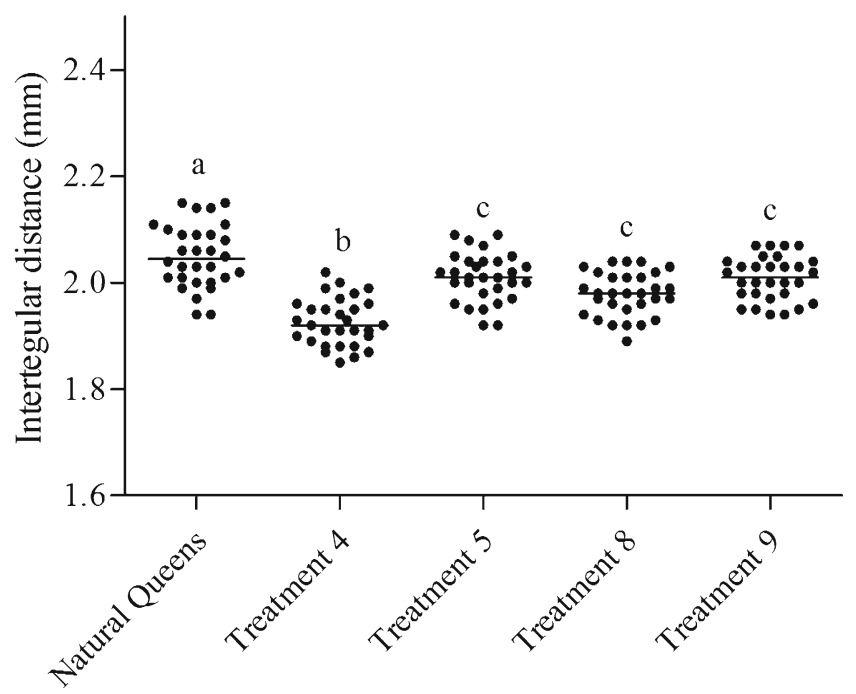

Figure 3. Size of in vitro queens produced under different humidity treatments compared with natural queens from royal cells of $S$. depilis. Each dot represents a measured queen and horizontal bars indicate the mean. Different letters above groups signify statistically significant differences at $P<0.05$, Tukey's test. Treatment description: $4100 \%$ during the first 3 days and $75 \%$ during the additional days of development; $5100 \%$ during the first 6 days and $75 \%$ during the additional days of development; $8100 \%$ during the first 3 days, $85 \%$ during the next 5 days, and $75 \%$ during the additional days of development; $9100 \%$ during the first 6 days, $85 \%$ during next 5 days, and $75 \%$ during the additional days of development. All treatments in this experiment received $134 \mu \mathrm{L}$ of larval food. 


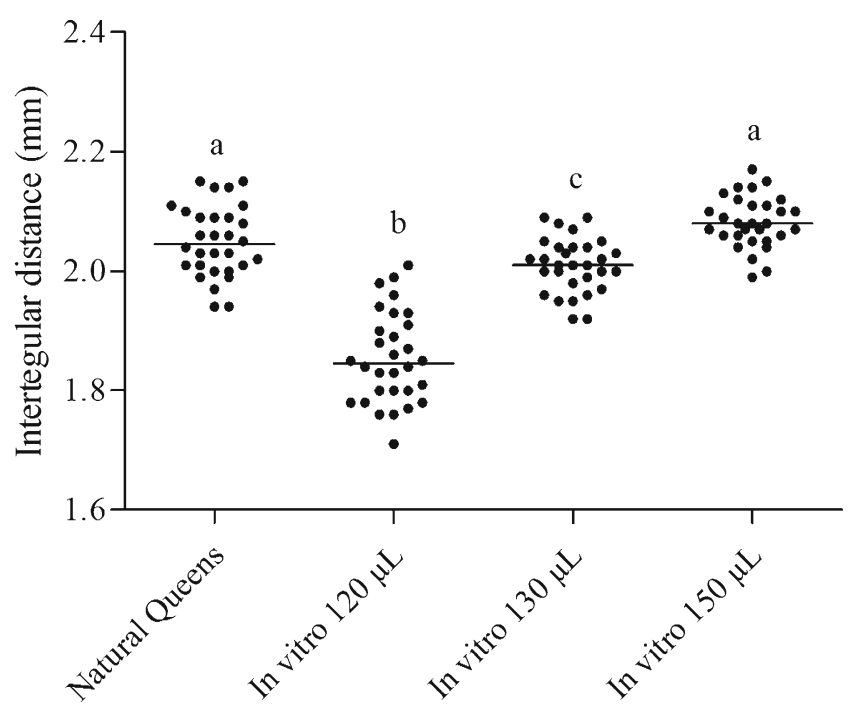

Figure 4. Intertegular distance as a measure of size of in vitro queens produced with different quantities of larval food $(120,134$, and $150 \mu \mathrm{L})$ and of natural queens. Each dot represents a measured queen, and horizontal bars indicate the median. Different letters above groups signify statistically significant differences at $P<0.05$, Tukey's test.

natural brood cells of healthy colonies, and the larvae eat them as they grow.

The main difficulty found was an infestation by the mite Tyrophagus putrescentiae. Infestation occurred twice and was responsible for the mortality of all the larvae and pupae that were developing inside the incubator. Adult mites, eggs, and mite feces were found on the pupae and larvae. T. putrescentiae is a common mite in humid domestic environments and feed on decomposing organic materials (C.H.W. Flechtmann, personal communication).

After these infestations, we adopted additional hygienic procedures during all queenrearing procedures and inspections. The incubator was sterilized every month with hypochlorite solution. The queen-rearing materials (acrylic cells, metal transfer hooks, Petri dishes, etc.) were also sterilized before larval transfer, and inspections were performed inside laminar flow hood to avoid contamination with external organisms. No further mite infestations occurred after these procedures were adopted.

\subsection{Are in vitro queens able to mate and lay eggs?}

Out of 50 introductions of in vitro produced queens to queenless colonies, 13 were successfully established, and the queens were able to mate and lay eggs. These colonies grew slowly but were considered independent after 6 months. One colony died after being formed due to an attack by another stingless bee species (Trigona spinipes). The other 36 colonies lost their in vitro queens for unknown reasons. We suspect the queens were lost during their nuptial flight.

\section{DISCUSSION}

In this study, we demonstrate that humidity control is very important during in vitro stingless bee queen-rearing. Stingless bees control the internal conditions of brood cells adding cerumen layers on the top of the recently built comb, making it very thick (Camargo and Pedro 2004). During brood development, this cerumen is removed and added to the new cells. This manipulation of the cells' wall allows a 
control of the internal condition of the cells, what must be kept in mind in the artificial queen rearing. Although humidity reduction during larvae development was already used by Camargo (1972a) and also adopted by other researchers (Almeida 1974; Campos and Costa 1989; Campos and Coelho 1993; Maciel-Silva and Kerr 1991; Hartfelder and Engels 1992), the artificial cells made from wax and closed with a wax cover made humidity control ineffective. In the first study by Camargo (1972a), only one queen emerged out of 40 transferred larvae. Survival rates were higher in later studies but still generally lower than $50 \%$ (Almeida 1974; Campos and Costa 1989; Maciel-Silva and Kerr 1991; Baptistella 2009; Prato 2011). These low survival rates were probably related to ineffective humidity control. Humidity inside the cells can be controlled using acrylic cells without a cover instead of closed wax cells. The absence of a cell cover did not harm the larvae, and humidity levels inside the Petri dish can be effectively controlled using saturated salt solutions (Winston and Bates 1960).

Another problem frequently found in previous stingless bee queen-rearing experiments was the difficulty of producing queens of a natural size. Hartfelder and Engels (1992) produced a large number of in vitro queens of $S$. postica and found that these queens were smaller than natural queens. Baptistella et al. (2012) also produced in vitro queens smaller than natural queens of Frieseomelitta varia. When we used the quantity we found in natural royal cells $(134 \mu \mathrm{L})$, we also obtained smaller queens (Figure 4 ). But by using $150 \mu \mathrm{L}$ of larval food, about $10 \%$ more than the average found in natural cells, we obtained queens of the same size of natural queens. Queen size is important, as in some species smaller queens lay fewer eggs than larger queens (Ribeiro 1998; Ribeiro and Alves 2001), although this was not found to be the case in all stingless bee species (Ribeiro et al. 2006).

Although in vitro queen rearing has been previously used to study the caste systems of stingless bees, it was not clear how fecund in vitro queens were. Camargo (1972a) was the first to show that in vitro queens were able to mate. Out of five in vitro queens, two were killed by workers before the nuptial flight, two never returned after their nuptial flight, and one mated successfully and laid eggs. Twenty years later, Hartfelder and Engels (1992) produced a large number of in vitro queens and compared their ovaries with natural queens' ovaries. They found that the ovaries of in vitro queens were differently sized and shaped if compared with those of natural queens, and the fecundity of the in vitro queens was questioned. This study reports successful in vitro production of $S$. depilis queens which were able to mate and lay eggs.

In vitro queen-rearing is an efficient way of obtaining large number of virgin stingless bee queens. When adequate conditions are provided, high survival rates can be achieved, and queens of the same size as natural queens can be produced. It is thus possible to produce hundreds of queens from a single colony in a short period of time. In vitro queen production may thus be usefully for both colony multiplication efforts and genetic improvement programs, likewise occurred with honeybees (Laidlaw and Page 1997). Although meliponiculture is still a modest economical activity, there is a growing interest in tropical areas for honey production and crop pollination. Thus, much more biological information and improvement of breeding techniques are required (Cortopassi-Laurino et al. 2006).

We have successfully produced 13 new colonies using only two brood combs and 150 young workers from the mother colony. Therefore, we used only $10 \%$ of a mature colony, since $S$. depilis has around 20 brood combs and 10,000 worker bees. Thus, this technique allows a single mother colony to produce several small ones, requiring in vitro queens. This seems to be an interesting possibility instead of splitting in half, which is the traditional way used so far (Nogueira-Neto 1997; Cortopassi-Laurino et al. 2006).

Recently, in vitro queens of several species were successfully produced (Nannotrigona testaceicornis (Menezes and Imperatriz-Fonseca 2008), T. angustula (Prato 2011), F. varia 
(Baptistella et al. 2012)). Although methods were slightly different, the principles used by these authors were the same as ours. For example, Baptistella et al. (2012) used a vacuum pump to harvest the larval food and stored it in a freezer at $-20^{\circ} \mathrm{C}$ before using, whereas we used fresh larval food in the present study. Therefore, the technique seems to be useful for several stingless species without severe changes.

We achieved a survival rate of almost $98 \%$. This is similar to the natural brood loss in Scaptotrigona colonies, which varies from 1$6 \%$, with an average of $3 \%$ (Flechtmann and Camargo 1974). Since we can obtain a survival rate similar to natural conditions, the technique will also have other uses, including exploring the nutrition and development of stingless bees, the effects of diseases, or testing pesticides. In vitro rearing of honey bees (A. mellifera) have been investigated and improved recently for these purposes (Brodshneider et al. 2009; Kaftanoglu et al. 2011). Therefore, stingless bees would also work as biological models for this kind of studies.

\section{ACKNOWLEDGMENTS}

We thank Fundação de Amparo a Pesquisa do Estado de São Paulo (FAPESP) for financial support, proc. 07/50218-1 and 04/15801-0. We also thank Tomer Czaczkes for reviewing this manuscript.

Une avancée dans l'élevage in vitro des reines d'abeilles sans aiguillon

Scaptotrigona depilis/Meliponini/multiplication des colonies/méliponiculture/pollinisateur

\section{Ein Fortschritt bei der künstlichen Aufzucht stachelloser Bienenköniginnen}

\section{Scaptotrigona depilis/Meliponini/Völkervervielfa- chung/Meliponikultur/Bestäuber}

\section{REFERENCES}

Almeida M.G. (1974) Aspectos bionômicos, ecológicos e genéticos da abelha Melipona scutellaris, Latreille (1811), PhD Thesis, University of São Paulo, Brazil.
Baptistella, A.R. (2009) Produção "in vitro" de rainhas e ocorrência natural de machos de Frieseomelitta varia (Apidae: Meliponina), Master Thesis. University of São Paulo, Brazil

Baptistella, A.R., Souza, C.C.M., Santana, W.C., Soares, A.E.E. (2012) Techniques for the in vitro production of queens in stingless bees (Apidae, Meliponini). Sociobiology 59, 297-310

Brodshneider, R., Riessberger-Galle, U., Crailsheim, K. (2009) Flight performance of artificially reared honeybees (Apis melliferra). Apidologie 40, 441449

Camargo, C.A. (1972a) Determinação de castas em Scaptotrigona postica Latreille (Hymenoptera, Apidae). Rev. Bras. Biol. 32, 133-138

Camargo C.A. (1972b) Produção "in vitro" de intercastas em Scaptotrigona postica Latreille (Hymenoptera, Apidae), in: Homenagem à W. E. Kerr, pp. 37-45.

Camargo, J.M.F., Pedro, S.R.M. (2004) Meliponini neotropicais: o gênero Ptilotrigona Moure (Hymenoptera, Apidae, Apinae). Rev. Bras. Entomol. 48, 353-377

Campos, L.A.O., Costa, M.A. (1989) Determinação do sexo em abelhas XXVIII. Determinação das castas em Schwarziana quadripunctata (Hymenoptera, Apidae). Rev. Brasil. Biol. 49, 999-1001

Campos, L.A.O., Coelho, C.D.P. (1993) Determinação de sexo em abelhas. XXX. Influência da quantidade de alimento e do hormônio juvenil na determinação de castas em Partamona cupira helleri (Hymenoptera, Apidae, Meliponinae). Rev. Bras. Zool. 10, 449-452

Cobey, S.W. (2007) Comparison studies of instrumentally inseminated and naturally mated honey bee queens and factors affecting their performance. Apidologie 38, 390-410

Cortopassi-Laurino, M., Imperatriz-Fonseca, V.L., Roubik, D., Dollin, A., Heard, T., Aguilar, I., Venturieri, G.C., Eardley, C., Nogueira-Neto, P. (2006) Global meliponiculture: challenges and opportunities. Apidologie 27, 275-292

Darchen, R., Delage-Darchen, B. (1971) Le déterminisme des castes chez les Trigones (Hyménoptères, Apidés). Insectes Soc. 18, 121-134

Engels, W., Imperatriz-Fonseca, V.L. (1990) Caste development, reproductive strategies and control of fertility in honey bees and stingless bees. In: Engels, W. (ed.) Social Insects: An Evolutionary Approach to Castes and Reproduction, pp. 167-230. SpringerVerlag, Berlin

Engels, W., Rosenkranz, P., Engels, E. (1995) Thermoregulation in the nest of the Neotropical stingless bee Scaptotrigona postica and a hypothesis on the evolution of temperature homeostasis in highly eusocial bees. Stud. Neotrop. Fauna Environ. 30, 193-205

Flechtmann, C.H.W., Camargo, C.A. (1974) Acari associated with stingless bees (Meliponidae, 
Hymenoptera) from Brazil, in: Proceedings of the 4th International Congress of Acarology. Saalfelden, Austria

Hartfelder, K., Engels, W. (1989) The composition of larval food in stingless bees: evaluating nutritional balance by chemosystematic methods. Insectes Soc. 36, $1-14$

Hartfelder, K., Engels, W. (1992) Allometric and multivariate analysis of sex and caste polymorphism in the neotropical stingless bee, Scaptotrigona postica. Insectes Soc. 39, 251-266

Hartfelder, K., Makert, G.R., Judice, C.C., Pereira, G.A.G., Santana, W.C., Dallacqua, R., Bitondi, M.M.G. (2006) Physiological and genetic mechanisms underlying caste development, reproduction and division of labor in stingless bees. Apidologie 37, 144-163

Imperatriz-Fonseca, V.L., Zucchi, R. (1995) Virgin queens in stingless bees (Apidae, Meliponinae) colonies: a review. Apidologie 26, 231-244

Kaftanoglu, O., Linksvayer, T.A., Page, R.E. (2011) Rearing honey bees, Apis mellifera, in vitro 1: effects of sugar concentrations on survival and development. J. Insect Sci. 11, 1-10

Laidlaw H.H.J., Page R.E.J. (1997) Queen rearing and bee breeding. Ed. Wicwas, Cheshire, CT

Maciel-Silva, V.L., Kerr, W.E. (1991) Sex determination in bees. XXVII. Castes obtained from larvae fed homogenized food in Melipona compressipes (Hymenoptera, Apidae). Apidologie 22, 15-19
Menezes, C., Imperatriz-Fonseca, V.L. (2008) Multiplicação de colônias de Nannotrigona testaceicornis (Hymenoptera, Apidae) utilizando rainhas produzidas in vitro, in: Anais do VIII Encontro sobre Abelhas de Ribeirão Preto. Ribeirão Preto, Brasil

Michener, C.D. (1974) The Social Behavior of Bees: A Comparative Study. Belknap Press, Harvard University Press, Cambridge Massachusetts

Nogueira-Neto, P. (1997) Vida e criação de abelhas indígenas sem ferrão. Editora Nogueirapis, São Paulo, Brazil

Prato, P. (2011) Ocorrência natural de sexuados, produção in vitro de rainhas e multiplicação de colônias em Tetragonisca augustula (Hymenoptera, Apidae, Meliponini), Master Dissertation. University of São Paulo, Ribeirão Preto, Brazil

Ribeiro, M.F. (1998) Size Polymorphism Among Queens of Stingless Bees, in: XIII, p. 394. Int. Congr. IUSSI, Adelaide, Australia

Ribeiro, M.F., Alves, D.A. (2001) Size variation in Schwarziana quadripunctata queens (Hymenoptera, Apidae, Meliponinae). Rev. Etologia 3, 59-65

Ribeiro, M.F., Santos-Filho, P.S., Imperatriz-Fonseca, V.L. (2006) Size variation and egg laying performance in Plebeia remota queens (Hymenoptera, Apidae, Meliponini). Apidologie 37, 653-664

Winston, P.W., Bates, D.H. (1960) Saturated solutions for the control of humidity in biological research. Ecology 41, 232-237 